\title{
Čudnovate zgode šegrta Hlapića: vertalend bruggen bouwen
}

\section{Čudnovate zgode šegrta Hlapića: building bridges through translation}

Maarten Rombouts, Paola Brodej

\begin{abstract}
Up until now there wasn't a Dutch translation of Čudnovate zgode šegrta Hlapića, the famous Croatian book for children, written in the early 1900's by the celebrated author Ivana Brlić-Mažuranić. It tells the universal story of an orphaned boy who is abused by his guardian and decides to escape which leads him on a seven-day journey. This article discusses the translation process and the choices made with a focus on the position of children's literature and its translation within the field of literary translations. In adult literature the goals of the authors are mainly literary, in children's literature the didactic and educational aspect is also included. A translator of children's literature has to take into account the different characteristics and functions of a book written for children which gives more freedom, but can also cause conflicts between the different function of a children's book. The translators of Čudnovate zgode šegrta Hlapića decided to stay as close as possible to the source but to implement adaptations that help the process of identification of the reader and the readability. The main focus of this article is on the translation of the meaningful names of the characters mainly using a naturalising strategy, trying to find a functional equivalent name which has, through sound or emotion, a similar effect as in the source text. Also adaptions in wording and phrasing were needed to bring an early twentieth century book to the twenty first century.
\end{abstract}

\section{Keywords}

translating, children's literature, Croatian, Dutch, Ivana Brlić-Mažuranić 


\section{Inleiding}

Čudnovate zgode šegrta Hlapića is één van de bekendste Kroatische kinderboeken. In het Nederlands kan de titel vertaald worden als: De wonderbaarlijke avonturen van leerjongen Lapje. Het boek werd in 1912 geschreven door de gevierde auteur Ivana Brlić-Mažuranić en voor het eerst gepubliceerd in 1913. Het is een klassieker in Kroatië en wordt nog steeds vaak gelezen. Het boek is tot nu toe vertaald in meerdere talen, waaronder Engels, Duits en zelfs Esperanto maar er is nog geen officiële Nederlandse vertaling. De auteurs van dit artikel hebben daarom een Nederlandse vertaling gemaakt. Bij deze vertaling hadden wij met meerdere uitdagingen te maken. Het vertalen van kinderliteratuur is op een aantal niveaus anders dan het vertalen van een ander literair werk. In deze bijdrage wordt aangevangen met het voorstellen van de auteur en het boek. Daarna wordt ingegaan op vertaaltechnische vraagstukken met betrekking tot het vertalen van een kinderboek. Vervolgens worden een aantal specifieke uitdagingen bij het vertalen van dit boek naar het Nederlands besproken. De nadruk ligt daarbij op de noodzakelijke aanpassingen die we nodig vonden om de brug te bouwen tussen de Kroatische maatschappij van eind negentiende, begin twintigste eeuw en het hedendaagse Nederlandse taalgebied.

\section{Over de auteur}

Ivana Brlić-Mažuranić werd in 1874 geboren in Ogulin, een kleine provinciestad in Kroatië. Haar vader was de zoon van de eerste Kroatische landvoogd die niet van adel was. Tevens was en is hij een beroemd en gevierd dichter. Haar moeder kwam uit een adellijke familie uit het noorden van het land. Haar kindertijd wordt vaak als idyllisch omschreven. De eerste sporen van haar interesse voor het schrijven zijn hier te vinden. Ze kreeg vooral huisonderricht, zowel van haar moeder als van verschillende privéleraars. Daardoor kon ze vloeiend Frans, Duits, Russisch en Engels spreken. Marietta, haar lerares Frans, groeide uit tot een goede vriendin en haar zelfmoord had een grote invloed op Brlić-Mažuranić. Veel van haar diepste gedachten zijn in haar bewaarde dagboeken te vinden.

$\mathrm{Na}$ haar huwelijk en het vroegtijdige overlijden van haar derde kind Vladimir kreeg ze met depressies te maken. In die tijd schreef ze nog niet zo veel, behalve af en toe een gedicht. Ze was voornamelijk bezig met haar familie en het huishouden. Toen in 1902 haar zesde kind Nikola vlak na zijn geboorte overleed, begon ze vaker en intensiever te schrijven. In datzelfde jaar werd met Valjani $i$ nevaljani haar eerste boek gepubliceerd waarmee ze onmiddellijk naam als auteur van kinderboeken verwierf. Na haar tweede hospitalisatie begon ze met het schrijven van Čudnovate zgode šegrta Hlapića. Het eindproduct van dat schrijfproces werd gepubliceerd in 1913. In het achterhoofd had ze kinderen tussen zes en acht jaar als doelpubliek (hlapic.org/o-romanu). Meer in het bijzonder schreef ze het voor haar neefje Ristić (Pentavec 2017: 15). Het boek werd vrij goed ontvangen door zowel het publiek als critici. 
De Eerste Wereldoorlog onderbrak het schijnbaar idyllische leven van de Brlić familie en tijdens de oorlogsjaren zorgde zij voor gewonden. Uit haar korte autobiografie geschreven in 1916 voor de Zuid-Slavische Academie van Kunsten en Wetenschappen blijkt dat zij dat jaar haar boek met kinderverhalen Priče iz davnine (Kroatische verhalen uit de oudheid) liet drukken. Dit boek bevat acht verhalen waar Slavische mythologie en traditionele Kroatische motieven zich mengen met haar buitengewone vermogen om handelingen levendig en krachtig voor te stellen, en het wordt terecht als haar meesterwerk beschouwd. De protagonisten zijn reuzen, feeën, Slavische geesten en goden, misleide en onbedachtzame mensen.

De jaren na de oorlog werden gedomineerd door familiale omstandigheden en problemen met armoede. Ze kreeg steeds meer erkenning maar tegelijkertijd voelde ze zich steeds slechter. In 1931 werd zij door de Joegoslavische Academie, de opvolger van de Zuid Slavische Academie voorgedragen voor de Nobelprijs voor Literatuur (Rendulić 2015: 80), die ze echter niet heeft gekregen. Haar depressies werden geleidelijk ernstiger en in 1938, zoals elke leerling op de basisschool kan lezen op de achterkant van haar boeken „eindigde zij haar leven door haar eigen wil“ (Pentavec 2017: 24).

\section{De context van het verhaal}

Ivana Brlić-Mažuranić maakte de eeuwwisseling van de negentiende naar de twintigste mee. Het was een voor Kroatië bewogen periode die gemarkeerd wordt door het uiteenvallen van het Oostenrijks-Hongaarse rijk. Dit gegeven is van belang voor de context van Čudnovate zgode šegrta Hlapića. Hoewel geschreven in 1913, plaatste de auteur het verhaal in 1885 op een moment dat de val van het rijk nog niet voorstelbaar was. Het verhaal speelt zich af in een agrarische pre-industriële maatschappij die typisch is voor deze tijd. Het grootste deel van haar leven bracht Ivana Brlić-Mažuranić door op een familielandgoed vlakbij een provinciestad. Het is niet moeilijk om dit soort omgeving te herkennen in haar verhaal over Hlapić hoewel de exacte geografische locatie niet gespecificeerd is. Daardoor kunnen de gebeurtenissen in het verhaal in elke agrarische regio plaatsvinden. Volgens Machata heeft het boek de opmerkelijke eigenschap universeel te zijn in tijd in cultuur. Daarnaast verbindt het realiteit en kinderverhalen (Machata 2013: 210). Dat is een van de redenen waarom het werk nu meer dan 100 jaar later nog steeds buitengewoon populair is in Kroatië. Zo werd het recent opnieuw verfilmd en staat het boek, samen met dat andere meesterwerk Priče iz davnine, op de verplichte literatuurlijst voor het basisonderwijs. Opvallend is dat het boek op de literatuurlijst voor het derde leerjaar staat. Dat komt overeen met een leeftijd van 7 tot 8 jaar waaruit blijkt dat er een lichte verschuiving van het kindbeeld heeft plaatsgevonden aangezien Brlić-Mažuranić het verhaal had bedoeld voor kinderen vanaf 6 jaar (hlapic.org/o-romanu). 


\section{Korte inhoud}

Het verhaal gaat over een jongen, Hlapić die als leerjongen in dienst is bij een schoenmaker, meester Mrkonja.

„Hlapić was zo klein als een muis maar hij was vrolijk als een vogeltje. De hele dag zat hij in een gescheurde broek en rood overhemd op een schoenmakersstoeltje dat drie poten had en de hele dag hamerde hij nagels in laarzen en naaide hij schoenen. De hele dag floot en zong hij tijdens het werk“ (Brlić-Mažuranić 2014: 19, eigen vertaling). ${ }^{1}$

Mrkonja is een grote, oude en angstaanjagende man.

„De voogd van Hlapić heette meester Mrkonja, die gemeen en angstaanjagend was. Hij was zo groot dat zijn hoofd tot aan het plafond van hun kleine kamer kwam. Zijn haar was altijd in de war zoals een leeuw en hij had een lange snor tot zijn schouders. Zijn stem was zo luid en krachtig als een beer. [...] Meester Mrkonja had dus een hard hart. Hij was echt oneerlijk. Telkens hij in een slechte bui was, vloekte en schreeuwde hij“ (Brlić-Mažuranić 2014: 19, eigen vertaling).

Zijn vrouw heeft in het boek geen naam. Er wordt naar haar verwezen als 'majstorica'. Een letterlijke vertaling hiervan is 'meesteres' maar om redenen die verder worden besproken, is dat geen goede vertaling. Zij is heel zachtaardig.

„Zijn vrouw was een heel goed persoon. Met haar is hetzelfde jammerlijk voorval gebeurd als met meester Mrkonja, maar sinds die tijd werd zij nog beter en ze had een heel goed hart. Ze hield veel van Hlapić. [...] Maar ze was bang van meester Mrkonja“ (Brlić-Mažuranić 2014: 19, eigen vertaling).

Zoals in deze passage wordt gesuggereerd, is er ooit iets heel ongelukkigs in hun leven gebeurd waardoor ze zijn hoe ze zijn.

Op een dag gaat er iets mis met een bestelling voor laarsjes waardoor Mrkonja heel boos wordt op Hlapić. Voor Hlapić is de emmer nu vol. Hij voelt zich onrechtvaardig behandeld en besluit weg te lopen om de wijde wereld in te gaan. Zo beginnen zijn wonderbaarlijke avonturen die zeven dagen duren. Onderweg ontmoet hij veel mensen en de woorden van de vrouw van Mrkonja indachtig, probeert hij te helpen waar hij kan zelfs als er slechte dingen gebeuren.

Qua thematiek kan worden opgemerkt dat het boek niet zo hard verschilt van Nederlandse boeken die in dezelfde tijdsperiode zijn geschreven en die ook nu nog steeds populair zijn. Denk hierbij aan de boeken met Dik Trom als hoofdpersonage of Afke's

1 De vertaling van het boek en bijgevolg de hiernavolgende passages werd door een masterstudent Neerlandistiek uitgevoerd onder begeleiding van de lector Nederlandse taalverwerving. 
tiental die ook focussen op kinderen in een agrarische omgeving. Vanuit dat opzicht lijkt een Nederlandse vertaling van Čudnovate zgode šegrta Hlapića welgekomen.

\section{Theoretisch kader: het vertalen van kinderliteratuur}

Zoals vastgesteld hoort Čudnovate zgode šegrta Hlapića bij het genre van kinderliteratuur. Dit roept bij het vertalen een aantal specifieke vragen op. Eerst wordt ingegaan op de specifieke positie die kinder- en jeugdliteratuur inneemt in het literaire spectrum. Deze positie heeft gevolgen voor het vertaalproces. Daaruit vloeit automatisch een relevante vraag voort. Is vertalen van kinderliteratuur anders dan vertalen van volwassenenliteratuur en zo ja, wat betekent dat dan voor de vertaling? Verschillende stellingnames in dit debat leiden tot een volgende grote vraag. Welke aanpassingen in de vertaling zijn vereist, gewenst of zelfs aanvaardbaar? In dit theoretische luik wordt er dieper op deze vragen ingegaan.

\section{De positie van kinderliteratuur}

Waar moeten we kinder- en bij uitbreiding jeugdliteratuur plaatsen als er wordt gekeken naar de gehele literaire productie? Om die vraag te beantwoorden moet deze vorm van literatuur eerste gedefinieerd worden. Ghesquière omschrijft het begrip jeugdliteratuur als gaande van kleurrijke prentenboek tot en met vuistdikke adolescentenromans (Ghesquière 2014, 11). In theorie kan jeugdliteratuur omschreven worden als alle literatuur die geen volwassenliteratuur is en dus een overkoepelend begrip is voor literatuur voor een lezerspubliek tussen 0 en 18 jaar. Ghesquière deelt dit echter nog eens op in kinderliteratuur tot 12 jaar en jeugdliteratuur tussen 12 en 15 jaar (Kamp 2019, 23). Čudnovate zgode šegrta Hlapića werd zoals eerder gesteld oorspronkelijk geschreven voor een lezerspubliek tussen 6 en 8 jaar oud. Daarom wordt in het vervolg van deze bijdrage over kinderliteratuur gesproken.

Volgens Koster werd kinder- en jeugdliteratuur vaak als secundair beschouwd ten opzichte van volwassenenliteratuur (Koster 2005: 57). Kinderliteratuur heeft een aantal specifieke kenmerken en functies die deze vorm van literatuur onderscheidt van volwassenenliteratuur. Kinderliteratuur kan met een literaire blik worden beschouwd en beoordeeld. Vanuit dit perspectief wordt bij de beoordeling van een kinderboek onder andere rekening gehouden met de ontspannende en de esthetische functie. Maar daarnaast bevat kinderliteratuur ook een pedagogische component. Kinderboeken hebben immers sinds het ontstaan van het genre ook een didactische functie. Algemeen wordt aangenomen dat de bundel Kleine gedigten voor kinderen die Hieronymus van Alphen publiceerde tussen 1778 en 1782 het eerste kinderboek in het Nederlands is. Dat betekent echter niet dat er voor die tijd niet voor kinderen werd geschreven (Kamp 2019, 43). De gedichten van Van Alphen zijn geschreven vanuit de leefwereld van kinderen maar ze bevatten ook steeds een wijze les. Opvoedkundige normen spelen een belangrijke rol 
aangezien kinderboeken geacht worden invloed te hebben op de opvoeding. Stevens zegt dat kinderliteratuur onder andere als doel heeft haar doelpubliek te socialiseren (Stevens 1992: 8). Dat is volgens Shavit de reden dat ze lange tijd minder serieus werden genomen als literaire werken maar enkel werden beoordeeld op hun educatieve functie (Shavit 1986: ix), een standpunt dat wordt gedeeld door O'Sullivan. Die zegt dat comparatieve literatuurwetenschappers het genre voor een groot deel hebben genegeerd hoewel kinderliteratuur taalkundige grenzen heeft overschreden en veel kinderboeken uitgaan van internationale paradigma's, meer dan van nationale (O 'Sullivan 2011: 190). Het is duidelijk dat kinderliteratuur een heel breed begrip is met meerdere lagen.

Het tweede grote onderscheid tussen volwassenenliteratuur en kinderliteratuur is de asymmetrische communicatie (Van Coillie 2005: 16). Op elk niveau, van de totstandkoming tot de aankoop van een kinderboek, vinden we volwassenen die voor kinderen de beslissing nemen of het nu gaat om de auteur, de uitgever, de criticus of de ouder die besluit het boek te kopen en zelfs de vertaler (O 'Sullivan 2011: 190). De vertaler speelt in het aanbod van kinder- en jeugdliteratuur in het Nederlandse taalgebied een belangrijke rol aangezien volgens Koster historisch gezien meer dan de helft van het voor Nederlandstalige kinderen beschikbare oeuvre vertaald is (Koster 2005: 59). Uit een onderzoek blijkt dat in 2005 er voornamelijk uit het Engels naar het Nederlands werd vertaald maar dat er grote verschillen bestaan per leeftijdscategorie (Koster 2005 (2): 71). De asymmetrie is vooral van belang omdat het een oordeel inhoudt van hoe volwassenen naar kinderen kijken en wat volwassenen wenselijk vinden voor kinderen en dat is niet noodzakelijkerwijs hetzelfde als hoe kinderen zichzelf bekijken. Zo belanden we bij veranderende kindbeelden, een ander belangrijk aspect dat een rol speelt bij het vertalen van kinderliteratuur.

De asymmetrische communicatie en de opvoedkundige dimensie van kinderboeken zijn onderhevig aan de tijdsgeest en aan het beeld dat een maatschappij heeft van wat een kind is, kan, mag of moet en dat beeld verandert voortdurend. Gouw definieert het kindbeeld als de voorstelling die elke volwassene heeft van een kind (Gouw 2016: 4). Dit beeld is constant aan een evolutie onderworpen en het huidige kindbeeld is een constructie van verschillende visies op het kind van de afgelopen eeuwen. Verderop in haar scriptie stelt Gouw dat er een spanning is tussen het idee dat kinderen onschuldig zijn en hun kind-zijn dus bewaard moet worden aan de ene kant en het idee dat het kind geëmancipeerd moet worden en dat het dus, onder andere via kinderliteratuur, kennis moet maken met de ruwere kant van het leven (Gouw 2016: 13). In de loop van de geschiedenis gaat deze pendel heen en weer. Zo ziet Van Coillie dat in de jaren zestig en zeventig jeugdliteratuur kindgericht moest zijn en moest aansluiten bij het niveau van de lezers en bij hun belevingswereld. In de jaren tachtig en negentig ziet hij een ontwikkeling van de autonomie en de esthetische functie bij kinderliteratuur (Van Coillie 2005: 17).

Toegepast op Čudnovate zgode šegrta Hlapića kan vastgesteld worden dat het kindbeeld van Ivana Brlić-Mažuranić ergens in het midden van deze twee uitersten zit. Het hoofdpersonage in het boek, Hlapić, maakt allerlei nare dingen mee. Hij wordt misbruikt door zijn leermeester, er is sprake van ontvoering, van diefstal, van armoede, maar al bij al 
heeft het boek een onschuldige toon en komt op het einde alles goed zonder blijvende trauma's. Ook moet worden opgemerkt dat de kinderen in het boek uitermate zelfstandig zijn en hun moeilijkheden oplossen zonder interventie van volwassenen. Meer zelfs, alleen aan het begin van het boek heeft een volwassene autoriteit over een kind. Daarmee verschilt het Kroatische kindbeeld van de vroege negentiende eeuw niet zo hard van het Nederlandse kindbeeld uit dezelfde periode. Als we het bijvoorbeeld vergelijken met een Nederlandse klassieker uit die tijd, Afke's tiental, valt op dat ook hier de kinderen tamelijk zelfstandig zijn.

\section{Vertalen voor kinderen}

Heeft de specifieke positie van kinderliteratuur gevolgen voor het vertaalproces? Deze vraag moet bevestigend worden beantwoord aangezien bij het vertalen van kinderboeken zowel taalkundige als opvoedkundige normen een rol spelen (Van Coillie 2005: 28). Voor hierop wordt ingegaan, wordt eerst de positie van het vertalen van kinderboeken in de vertaalwetenschap nader beschouwd. Koster zegt met een boutade dat een vertaling van een kinderboek vaak als weinig anders dan het verminkte broertje van het origineel werd gezien (Koster 2005: 57). Gouw bevestigt dit. „Kinderliteratuur werd binnen het literaire systeem lange tijd van geringe waarde geschat. Hetzelfde valt te zeggen voor de aandacht die kinderliteratuur kreeg binnen de vertaalwetenschap“ (Gouw 2016: 15). Dit heeft te maken met de gecombineerde rol van vertaler en auteur die we in kinderliteratuur vaker tegenkomen dan in volwassenenliteratuur (Koster 2005: 61). Shavit zegt hierover dat dat onder andere komt omdat de vertaler van kinderliteratuur zich veel meer vrijheden kan veroorloven. Daarmee bedoelt ze dat het de vertaler is toegestaan om de tekst op verschillende manieren te manipuleren zolang aan twee principes wordt voldaan. Ten eerste moet de manipulatie gebeuren op zo'n manier dat de vertaling tegemoetkomt aan wat de maatschappij als goed voor het kind beschouwt (het didactische aspect van kinderliteratuur) en ten tweede moet een aanpassing zo gebeuren dat ze beantwoordt aan het beeld dat de maatschappij heeft van de leesvaardigheden van het kind (Shavit 1986; 112). Koster stelt dat het verschil „niet in de veronderstelde speelruimte van de vertaler ligt maar in het feit dat er veel meer variatie bestaat in de vormen van vertaling die aanvaardbaar worden geacht" (Koster 2005: 64).

Daarbij moet ook worden opgemerkt dat de verschillende functies van kinderliteratuur met elkaar in conflict komen bij de vertaling. Als de vertaler bijvoorbeeld de didactische functie van kinderliteratuur laat voorgaan, zal hij de vertaling meer aanpassen aan het heersende kindbeeld wat een invloed heeft op de woordkeuze, op de nood om dingen meer uit te leggen of net weg te laten en zo verder weggaan van de brontekst en de oorspronkelijke stijl. Zo belanden we bij de eeuwige discussie in de vertaalwetenschappen, aanpassen of niet en zo ja, tot op welk niveau?

Twee belangrijke stellingnemers in dit debat met betrekking tot kinderliteratuur zijn de Zweedse onderzoeker Göte Klingberg en de Finse Riita Oittinen. Klingberg stelt dat hoe meer er wordt aangepast in een tekst, hoe beter die tekst te lezen is. Maar voor 
hem gebeurt die aanpassing op het niveau van de auteur en niet die van de vertaler. Bij het schrijven heeft de originele auteur al rekening gehouden met het leespubliek. Dat betekent dan dat de enige taak van de vertaler is om hetzelfde niveau van aanpassing te behouden (Oittinen 2000: 89). Elke andere aanpassing van de vertaler evalueert hij als negatief. Oittinen vindt deze benadering problematisch en stelt zichzelf de vraag waarom vertalers geen gemoderniseerde vertaling zouden mogen maken, een die is aangepast aan de tijd en de plaats van het doelpubliek (Oittinen 2000: 90).

Voor beide posities zijn argumenten pro en contra te vinden. Bij de Nederlandse vertaling van Čudnovate zgode šegrta Hlapića is voor een gulden middenweg gekozen. Het uitgangspunt was om zo dicht mogelijk bij de brontekst te blijven maar net die aanpassingen door te voeren waar dat zou helpen bij de herkenbaarheid en identificatie en bij de leesbaarheid, wat toch cruciale aspecten zijn bij het beoordelen van kinderliteratuur. Er mag immers niet worden vergeten dat kinderen nog niet zo veel leeservaring hebben. In wat volgt, worden een aantal doorgevoerde aanpassingen voorgesteld maar eerst gaan we kort in op welke soorten aanpassingen er mogelijk zijn.

\section{Soorten aanpassingen}

Van Coillie onderscheid drie soorten aanpassingen vanuit drie verschillende beweegredenen (Van Coillie 2005: 17). Ten eerste zijn er aanpassingen aan de cultuur die gebeuren vanuit een verschil in kennis met drie mogelijke strategieën zijnde exotiseren, neutraliseren en naturaliseren. Culture aanpassingen kunnen op verschillende gebieden. Denk aan persoonsnamen, geografische benamingen, gebruiken, tradities, voeding, ... Zoals verder beschreven, is er in de vertaling van Čudnovate zgode šegrta Hlapića vooral gebruikt gemaakt van een naturaliserende benadering van persoonsnamen. Toponiemen zijn niet aanwezig in het boek behalve Beč wat de Kroatische benaming is voor Wenen en dus geen aanpassing is maar gewoon een vertaling.

Dan onderscheidt hij aanpassingen van verwoording en plot om de leesbaarheid en het leesplezier te vergroten. Ook dit is gebeurd in de vertaling zoals verder wordt besproken.

Tot slot merkt Van Coillie op dat er ook aanpassingen aan waarden en normen kunnen gebeuren. Dit houdt direct verband met de didactische functie van kinderliteratuur en het bestaande kindbeeld. Met dit soort aanpassingen zijn de vertalers niet aan de slag gegaan.

\section{De vertaling - vraagstukken en uitdagingen}

We hebben ons gebaseerd op een niet-herwerkte versie van het boek. Deze versie van het boek is minder verspreid dan de herwerkte die verder ligt van de originele uitgave en dus veel verder van de originele woorden en intenties van de auteur. Door deze keuze staat de Nederlandse vertaling dichter bij het origineel. In de vertaling moest een 
brug worden geslagen tussen de Kroatische maatschappij uit de jaren 1910 en die van het Nederlandse taalgebied nu. Dat speelt op meerdere niveaus. In het verhaal zijn de namen van de personages heel belangrijk. Kunnen deze zomaar worden behouden, of zijn ook hier aanpassingen nodig? Deze vragen situeren zich meer op het domein van herkenbaarheid en identificatie en vereisen culturele aanpassingen.

Ook op het domein van leesbaarheid zijn er vragen. Het verhaal is meer dan een eeuw geleden geschreven en bevat een aantal archaïsche woorden die nu niet meer in het Kroatisch gebruikt worden. Daarnaast is de literaire stijl veranderd. Het is interessant hierbij op te merken dat Brlić-Mažuranić zelf aangeeft dat ze streefde naar eenvoudige en heldere taal zodat de karakters en de scènes in het boek authentiek overkomen bij kinderen (Brlić-Mažuranić 1994: 112). Vanuit een hedendaags standpunt valt echter op dat ze vaak kiest voor nogal lange zinnen met veel (exacte) herhalingen en, hoewel dat ook geldt voor Nederlandstalige kinderliteratuur uit die tijd, is dat een stijl die nu minder geassocieerd wordt met kinderboeken. Om de leesbaarheid te vergroten, zijn er in de vertaling een aantal aanpassingen geweest die betrekking hebben tot de verwoording. Ook dit wordt verder besproken.

\section{Aanpassingen in de vertaling}

In de Nederlandse vertaling van Čudnovate zgode šegrta Hlapića werd op twee manieren aangepast. Ten eerste zijn er een aantal culturele aanpassingen. Daarnaast zijn er een aantal aanpassingen aan de verwoording.

Aanpassingen aan de cultuur gebeuren wegens een verondersteld verschil in kennis. Zal de huidige generatie kinderen de context van het verhaal nog wel begrijpen? Volgens Machata, die een uitgebreide studie heeft gemaakt over de vertaling van het verhaal naar het Slovaaks, heeft het boek de opmerkelijke eigenschap universeel te zijn in tijd in cultuur (Machata 2013: 210). Voor de Nederlandse vertaling wordt deze veronderstelling gevolgd. De meeste aanpassingen aan de cultuur die in deze vertaling zijn toegepast hebben betrekking op de namen van de personages. Daarnaast moest ook de benaming van de munteenheid worden aangepast.

Bij het vertalen van een Slavisch werk uit de vroege twintigste eeuw naar het Nederlands van de eenentwintigste eeuw zijn er ook aanpassingen aan de verwoording nodig als het doel is dat het boek soepel leesbaar en begrijpelijk blijft.

„Een goede literaire vertaling van een kinderboek moet trouw zijn aan de brontekst, maar ook een soepel leesbaar en begrijpelijk boek opleveren. Eigenlijk moeten er dezelfde eisen aan gesteld worden als aan een literaire vertaling, met dus nog een zware extra eis“ (Van Coillie 2005: 22).

Bij drie namen van personages werden om de leesbaarheid een aantal aanpassingen aan de verwoording toegepast. Het gaat daarbij om fonetische aanpassingen en eenmaal om een morfologische aanpassing. Daarnaast werd er aandacht besteed aan een aantal 
stilistische elementen, zoals het gebruik van lange zinnen, het overmatige gebruik van leestekens en herhalingen, het taalgebruik en de werkwoordstijden. In wat volgt wordt er eerst ingegaan op de naamgeving van de personages, de aanpassing van de munteenheid, om te eindigen met voorbeelden waarbij de verwoording werd aangepast.

\section{Naamgeving}

De grootste uitdaging waar de vertalers voor stonden, waren de namen die Ivana Brlić-Mažuranić aan haar karakters heeft toegekend. Alle personages in het boek hebben een erg Slavische naam die voor Nederlandstaligen moeilijk uit te spreken is wat de herkenbaarheid en identificatie niet ten goede komt, net als het leesplezier. Het was mogelijk om deze namen in hun originele vorm te laten staan, vanuit het idee dat het een verrijking is om kinderen in contact te brengen met andere culturen. De meeste namen hebben echter ook een (soms subtiele) betekenis of associatie die weliswaar niet zo belangrijk is om het verhaal te begrijpen maar wel iets extra's toevoegen aan de leesbeleving. Het was daarom belangrijk om de betekenis van de namen zoals door Brlić-Mažuranić bedoeld te achterhalen.

Om deze reden is gekozen voor een culturele adaptatie waarbij de namen zo goed mogelijk werden aangepast en tegelijkertijd zo dicht mogelijk bij de brontekst bleven. Hier en daar is er enkel voor een aanpassing in verwoording gekozen. Zoals eerder vermeld kunnen namen op verschillende manieren worden aangepast. Er kan worden geopteerd voor een exoniem waarbij de naam wordt vervangen door de pendant in de doeltaal waarbij de Kroatische Ivan de Nederlandse Jan wordt en de Kroatische Pavao dan Paul wordt. In de meeste vertalingen van Čudnovate zgode šegrta Hlapića is te merken dat er vaak voor zo'n strategie is gekozen of dat de spelling van de naam fonetisch werd aangepast zodat een foutieve uitspraak wordt vermeden. De in de Nederlandse vertaling vaakst gebruikte strategie bij de vertaling van de namen is een naturaliserende strategie waarbij, zoals Van Coillie het mooi omschrijft, getracht is een 'functioneel equivalente' naam te vinden die door klank, gevoelswaarde of humor een vergelijkbaar effect heeft als in de brontekst (Van Coillie 2005, 19). Er werd geen exotiserende strategie gebruikt, waarbij namen gewoon worden overgenomen, eventueel met een verduidelijking. In het geval van één personage, Majstorica, werd een neutraliserende strategie gekozen waarbij de naam werd vervangen door een omschrijving, zoals hierna wordt uitgelegd.

\section{Hapić}

De naam van het hoofdpersonage bleek een grote uitdaging te zijn. In andere vertalingen is er gekozen om de naam min of meer hetzelfde te houden met slechts een fonetische aanpassing: Lapitch in het Engels, Clapitsch in het Duits, Lápich in het Spaans. Die analogie volgend had bijvoorbeeld Lapitsj een aanvaardbaar Nederlands alternatief kunnen 
zijn. Toch is daar niet voor gekozen omdat Lapitsj in de eerste plaats nog steeds moeilijk uit te spreken is voor jonge kinderen wat de identificatie kan verminderen. De tweede en belangrijkere reden is omdat in de naam Hlapić een aantal verborgen betekenissen zitten die de meeste Kroaten nu ook niet meer begrijpen. Hlap is immers een heel oud woord. Vertaald naar het Nederlands wordt dat lijfeigene, horige of laat. Het is een verwijzing naar de ondergeschikte toestand waarin de leerjongen zich bevindt. Hij is geen eigenaar van zijn eigen toekomst. Het Kroatische suffix -ić duidt op een verkleinwoord. In eerste instantie kozen de vertalers voor de naam Laatje als vertaling voor Hlapić. Een laat, in het Nederlands een verouderd woord, was in het middeleeuws feodaal systeem een gedeeltelijk onvrije boer. In die vertaling is ook het diminutief meegenomen en er is een klankrijm: Hlapic - Laatje. Hierbij moet worden opgemerkt dat het Kroatisch geen onderscheid maakt tussen lange en korte klinkers. Het probleem hiermee is echter dat de meeste Nederlandstaligen de naam zouden lezen als een kleine lade. Daarom is ervoor gekozen om Hlapić te vertalen als Lapje. In die vertaling zit ook het klankrijm en er is een verwijzing naar het oude werkwoord schoenlappen. Er werd hier dus voor een naturaliserende strategie gekozen.

\section{Majstor Mrkonja}

De naam van de leermeester was zo mogelijk nog een grotere uitdaging. Het eerste deel van zijn naam liet zich vanzelfsprekend en vlot vertalen door meester. Daarin zit zowel het aspect van onderwijzer als dat van hiërarchisch hogergeplaatste. Mrkonja daarentegen is moeilijker te vertalen omdat de naam in het Kroatisch duidelijke associaties heeft en bepaalde beelden oproept die het karakter typeren.

In Mrkonja is het Kroatische woord mrk te herkennen wat slechtgezind betekent. Daarnaast is er ook een verwijzing naar het Kroatische woord mrak wat donker of duister betekent. Beide betekenissen zijn duidelijke verwijzingen naar het karakter van de leermeester. In Slavische talen is de vertaling een stuk eenvoudiger. Zo is Majstor Mrkonja in het Slovaaks vertaald als majster Mrkoň met een verwijzing naar het Slovaakse woord $m r k$ wat schemering betekent en zo is een belangrijk deel van de oorspronkelijke associatie behouden. De Engelse vertaling voor Mrkonja is Master Scowler. Deze naam is afgeleid van het Engelse werkwoord to scowle wat in het Nederlands zoveel is als fronsen of boos kijken. Op zich een goed idee maar het geeft een iets te enge weergave van de oorspronkelijke betekenis en dus het karakter van Mrkonja weer. De duistere kant van zijn karakter is immers even belangrijk zo niet belangrijker omdat hij zo is door iets wat er in het verleden is gebeurd en wat de lezer pas op het einde van het boek ontdekt.

Daarnaast werd de keuze gemaakt om de naam van dit personage te veranderen van een voornaam naar een achternaam. Hoewel het in het Nederlands natuurlijk klinkt om na de titel meester, en dan vooral in een lagere schoolcontext, een voornaam te laten volgen, is er in de vertaling voor een achternaam gekozen. De reden hiervoor wordt later in dit artikel uit de doeken gedaan als er wordt gesproken over het personage van de vrouw van Majstor Mrkonja. 
Om de associaties verbonden met de naam in het Nederlands te behouden, zijn er meerdere opties. Tijdens het vertaalproces kwamen volgende alternatieven voor de dag: Meester Den Doncker, meester Duyster, meester Bitterbyt en meester Sombermans. Uiteindelijk is er gekozen voor meester Sombermans omdat die naam zowel het ritme als de klank van de originele naam het meeste benadert. Ook hier is dus geopteerd voor een naturaliserende stragegie.

\section{Majstorica}

Majstorica is de vrouw van meester Sombermans. Haar benoemen in de vertaling was een probleem aangezien Brlić-Mažuranić haar geen naam heeft gegeven. Er wordt enkel naar haar verwezen als Majstorica. Het suffix -ica in het Kroatisch geeft hier weer dat het over een vrouw gaat. Dit is heel normaal in het Kroatisch en houdt geen enkel waardeoordeel in zoals soms wel in het Nederlands waar het problematisch wordt als je het woord meester een vrouwelijk suffix geeft. Een meesteres is iets heel anders dan wat Brlić-Mažuranić bedoelde met Majstorica. Meesteres heeft immers een heel duidelijke seksuele connotatie.

In een onderwijscontext, waarvan hier ook sprake is, is het vrouwelijke equivalent van meester, juffrouw. Maar dit kan niet werken omdat Majstorica ook de vrouw van Majstor Mrkonja is en een juffrouw per definitie een ongetrouwde vrouw is.

Om deze redenen is er geopteerd voor een neutraliserende strategie waarmee naar dit personage op twee manieren wordt verwezen in de vertaling: de vrouw van meester Sombermans of mevrouw Sombermans. Geen van beide keuzes leidt tot optimale tevredenheid aangezien de eerste het personage te hard in een context van afhankelijkheid van haar man plaatst. Het lijkt als het ware alsof een echtgenote zijn haar enige reden van bestaan is. De optie mevrouw Sombermans laat haar te streng overkomen wat niet in lijn is met haar karakter. $\mathrm{Zij}$ is immers een zachtaardige en warme figuur. Hier is dus meer gekozen voor een neutraliserende strategie.

\section{Bundaš}

Lapje krijgt op zijn avontuur het gezelschap van zijn trouwe en slimme hond Bundaš. Hier stelt de vertaling zich voor minder problemen. Bunda betekent in het Kroatisch bont wat natuurlijk het beeld opwekt van een harige vriend. De vertalers hadden twee opties voor de Nederlandse naam voor Bundaš. De eerste is Pelsje, wat heel lief en vriendelijk klinkt en meer geschikt voor kinderen. Het alternatief is Bontje, wat dichter bij de brontekst ligt en als voordeel heeft dat er weer een beginrijm en klankrijm is. Er is in beide opties gekozen voor een verkleinwoord. De keuze is uiteindelijk gevallen op Bontje als die optie die het dichtste aansluit bij de originele naam. Bij de vertaling van Bundaš werden zowel een naturaliserende strategie toegepast, net als een aanpassing op morfologisch niveau door de toevoeging van een verkleinend suffix. 


\section{Gita}

Een volgend belangrijk personage in het boek is Gita. Lapje ontmoet haar onderweg en ze zal een uitermate belangrijke rol spelen. In het verhaal is Gita een circusartieste. De naam Gita is ook in het Kroatisch een ongewone naam, zoals Brlić-Mažuranić zelf aangeeft in het boek: „, het was een beetje een vreemde naam, maar in het circus zijn er wel meer vreemde dingen" (Brlić-Mažuranić 2014: 51).

De naam Gita heeft op meerdere niveaus een speciale betekenis. Het is een universele naam die in veel landen voorkomt. Origineel komt de naam uit het Sanskriet en betekent hij Parel of Lied (Bhagavadgita). Verder komt de naam vaak voor bij Roma en kan zo ook verbonden worden aan het circus. Het is hier interessant om aan te stippen dat er een gerucht bestaat dat Brlić-Mažuranić zelf ook Roma-bloed had. We hebben ervoor gekozen om Gitta te behouden maar de spelling om fonetische redenen aan te passen.

\section{Marica}

Op het einde van het verhaal wordt Gitta herkend als Marica, de lang verloren dochter van de Sombermansen. Hoe ze herkend wordt, is op zich al een interessant verhaal dat karakteristiek is voor Brlić-Mažuranić omdat het verwijst naar oude gebruiken. Toen ze klein was, had Marica zich gesneden met een mesje wat op haar duim een litteken in de vorm van een kruisje achterliet. Aan dat kruisje herkennen haar ouders haar. Dit kruisje kan een verwijzing zijn naar een oud gebruik in Kroatië. In dat gebruik kregen christelijke kinderen een kruisje op hun arm getatoeëerd om hen te beschermen tegen ontvoering door de Turken of Roma of om ontvoerde kinderen te laten herinneren dat het christenen zijn of om hen te onderscheiden van hun ontvoerders.

De naam Marica kan op twee manieren vertaald worden. De eerste optie is Grietje. Dan wordt het een verwijzing naar Hans en Grietje, het oude sprookje dat bekendheid verwierf door de gebroeders Grimm. Dit lijkt een vreemde keuze maar er zit een logica in. In het Kroatisch is de titel van dat sprookje immers Ivica en Marica waar de mogelijkheid bestaat dat Brlić-Mažuranić doelbewust voor deze naam koos want zoals in het sprookje, komt Marica na een gevaarlijk avontuur weer thuis. De vertalers gaan er ook van uit dat de meeste kinderen dit sprookje wel kennen waardoor de herkenbaarheid en identificatie met het personage wordt vergroot. De andere optie is om Marica te beschouwen als het verkleinwoord van Maria. Dan is een mooie vertaling Marijke met het meer Vlaamse diminiutief -ke waarbij de link wordt gemaakt naar het kruisje en religie. De voorkeur werd gegeven aan Marijke, opnieuw vanwille de grootste gelijkenis met de originele naam waarbij gebruik werd gemaakt van een naturaliserende strategie. 


\section{Crni Čovjek en Grga}

Verder zijn er in het verhaal nog twee slechteriken. De eerste is onomwonden slecht en wordt door Brlić-Mažuranić benoemd als Crni Čovjek wat letterlijk te vertalen is als de zwarte man.

Het andere personage, Grga, krijgt tijdens het verhaal berouw van zijn slechte daden. De naam kan naar veel verschillende Gregoriussen verwijzen maar de meest interessante gedachtegang is dat Grga een verwijzing is naar het 12de eeuwse gedicht Gregorius - de goede zondaar van Hartmann von Aue. In dat gedicht is het hoofdpersonage Gregorius een zondaar die berouw toont. Het is niet te bewijzen dat Brlić-Mažuranić dit gedicht kende, maar het is een interessante gedachtegang. In de Nederlandse vertaling wordt Grga Gregor. Hier is enkel gebruikgemaakt van een fonetische aanpassing die de leesbaarheid vergroot,

\section{Miško}

Verder willen we het ook hebben over de herdersjongen Miško. Miško is een olijke maar heel kleine jongen die allerlei streken uithaalt. Een logische en meer letterlijke vertaling van deze naam is Muisje waarbij de alliteratie behouden blijft en verwezen wordt naar het Kroatische miš, wat muis betekent en het aspect wordt bewaard dat hij heel klein is. Een andere optie is Bollie omdat hij in het boek niet enkel als klein wordt omschreven maar ook als dik. Ook is het geen grijs personage, waar Muis in het Nederlands toch de associatie opwekt van een nogal kleurloos persoon, terwijl Bollie toch meer actie en vooral kattenkwaad oproept.

\section{Munteenheid}

Naast de naamgeving is er nog een culturele aanpassing die in de Nederlandse vertaling is toegepast gebruikmakend van een naturaliserende strategie. Het gaat over de benaming van valuta. In Čudnovate zgode šegrta Hlapića wordt er geld gebruikt. De munteenheid in het boek is de forint. Dat was toen de munteenheid in wat nu Kroatië is en het is nog steeds de munteenheid van Hongarije. Er is gekozen om dit in het Nederlands naar florijn te vertalen. Zowel het woord forint als florijn hebben een gemeenschappelijke etymologie. Beide zijn vernoemd naar de Italiaanse stad Firenze waar de eerste belangrijke gouden munt werd geslagen. De vroegere Nederlandse munteenheid, de gulden, is in feite een verwijzing naar een gouden (gulden) florijn. Dat verklaart ook waarom de afkorting voor een Nederlandse gulden „f“ of „fl“ was. Nadeel voor deze keuze is dat lezertjes uit België hier waarschijnlijk niet bekend mee zijn.

Samengevat werd er bij het vertalen van de namen en de munteenheid vanuit een verschil in kennis vooral gekozen voor een naturaliserende strategie waarbij erop gelet is dat de vertaling in de doeltaal een door klank, gevoelswaarde of humor een vergelijk- 
baar effect heeft. Eenmaal is er voor een neutraliserende benadering gekozen waarbij het personage Majstorica geen eigen naam meer heeft maar in de Nederlandse vertaling bekend staat als de vrouw van of mevrouw. Twee namen, Gitta en Gregor, werden enkel fonetisch aangepast en een naam, Bontje, kreeg een verkleinend suffix.

\section{Aanpassingen in de verwoording}

In wat volgt worden een aantal voorbeelden gegeven van aanpassingen in de verwoording die noodzakelijk werden geacht om de leesbaarheid van het verhaal te verbeteren. Het gaat daarbij om een stilistische aanpassingen,

\section{Stilistische aanpassingen}

„Hlapić je bio još malen kao lakat, a veseo kao ptica. Cijeli dan je sjedio Hlapić u poderanim hlačama i crvenoj košulji na malom postolarskom stolcu, koji je imao tri noge, i cijeli je dan zabijao klince u čizme i šivao cipele. I cijeli dan je fućkao i pjevao kod posla“ (Brlić-Mažuranić 2014: 19).

Als dit fragment letterlijk wordt vertaald, gebeurt het volgende.

Hlapić was nog zo klein als een elleboog, maar hij was vrolijk als een vogeltje. De hele dag zat hij in een gescheurde broek en rood overhemd op een schoenmakersstoeltje, dat drie poten had en de hele dag hamerde hij nagels in laarzen en naaide hij schoenen. En de hele dag floot en zong hij tijdens het werk (Brlić-Mažuranić 2014: 19, eigen vertaling).

In een aangepaste vertaling wordt de metafoor klein als een elleboog die in het Nederlands onbekend is, veranderd naar klein als een muisje. De zinnen worden verkort zodat er in het algemeen maar één persoonsvorm is per zin. Komma's die zo typisch zijn voor het Kroatisch maar overbodig in het Nederlands worden verwijderd. In dit fragment wordt de herhaling de hele dag wel gebruikt omdat het een vloeiend ritme geeft.

Lapje was zo klein als een muisje en vrolijk als een vogeltje. De hele dag zat hij in zijn gescheurde broek en rood hemdje op een schoenmakerstoeltje met maar drie poten. De hele dag hamerde hij nagels in laarzen en naaide hij schoenen. De hele dag floot hij en zong hij tijdens het werk (Brlić-Mažuranić 2014: 19, eigen vertaling).

\section{Lexicale aanpassingen}

Brlić-Mažuranić gebruikt, logischerwijze, een aantal woorden die nu archaïsch aandoen. Hieronder wordt een voorbeeld besproken van dit soort aanpassingen.

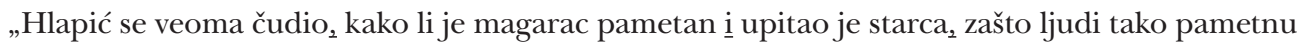
životinju nazivaju magarac iliti osal?“ (Brlić-Mažuranić 2014: 31). 
In de vertaling wordt dat:

Lapje was heel verbaasd dat een ezel zo slim is. Hij vroeg de oude man waarom mensen zo'n slim dier een ezel noemen (Brlić-Mažuranić 2014: 31, eigen vertaling).

In deze vertaling kon niet anders dan een neutraliserende strategie te gebruiken waarbij het woord osal werd weggelaten. Letterlijk zou deze passage vertaald worden als: Hij vroeg de oude man waarom mensen zo'n slim dier een ezel oftewel een ezel noemen. Osal is niet alleen een heel oud Kroatisch woord. Het wordt tevens in een dialectvorm gebruikt die typerend is voor het zuidelijk deel van Kroatië waarin de uitgang -ao vaak vervangen wordt door de uitgang -al. Het woord osao betekent net als magarac ezel. In het Nederlands bestaat er geen archaïsch synoniem voor ezel. Zelfs als er een archaïsch synoniem zou bestaan, lijkt het niet opportuun om dat te gebruiken. De reden waarom Brlić-Mažuranić dit toch doet, is waarschijnlijk om het domme en koppige karakter van een ezel te benadrukken. Er wordt vanuit gegaan voor de vertaling dat de jonge lezertjes voldoende bekend zijn met dit stereotiepe beeld zonder het expliciet te benadrukken. De context waaruit dit citaat komt, maakt dit ook duidelijk.

\section{Grammaticale aanpassingen}

Qua grammatica is er vooral aandacht besteed aan de werkwoordstijden met nadruk op het veelvuldig gebruik van de historische presens. De historische presens waarbij gebeurtenissen in het verleden in de onvoltooid tegenwoordige tijd worden geschreven, is heel erg normaal in het Kroatisch. In het Nederlands gebeurt dit ook wel maar toch vooral in historische werken, wat dit verhaal zeker niet is. Het hele verhaal speelt zich af in de verleden tijd maar zoals bijvoorbeeld uit het volgende fragment blijkt, wordt er in het gebruik van de werkwoorden geregeld overgegaan naar de tegenwoordige tijd, het zogenaamde historische presens. Het is vooral de afwisseling tussen de verleden tijd en het historisch presens die verwarrend werkt in het Nederlands en niet alleen voor de jonge lezertjes.

„Sluškinja se zasrami, što se nije sama na to sjetila i obeća Hlapiću, da će ići svaki dan dolje po mlijeko.A Hlapić joj obeća, da će joj donijeti cvijeća sa puta. Kad je Hlapić došao dolje k starcu, umoli on njega da mu smije još pomoći raznieti mlieko, jer su kola još bila puna kanta“ (Brlić-Mažuranić 2014: 31).

In een letterlijke vertaling geeft dat het volgende:

De dienstmeid schaamt zich dat ze niet zelf op dat idee was gekomen en belooft aan Lapje dat ze vanaf nu elke dag alleen naar beneden zal gaan om de melk te halen. Dan belooft Lapje haar dat hij haar van zijn reis bloemen zal brengen. Toen Lapje weer beneden op straat bij de oude man kwam, verzoekt hij hem om hem verder te laten helpen met melk rond te brengen want er staan nog veel melkkannen op het wagentje (Brlić-Mažuranić 2014: 31, eigen vertaling). 
Beter echter is dit fragment als volgt te vertalen:

De dienstmeid schaamde zich dat ze niet zelf op dat idee was gekomen en beloofde aan Lapje dat ze vanaf nu elke dag naar beneden zou gaan om de melk te halen. Lapje beloofde haar van zijn kant dat hij haar van zijn reis bloemen zou brengen. Toen Lapje weer beneden op straat bij de oude man kwam, verzocht hij hem om hem verder te laten helpen met melk rond te brengen want er stonden nog veel melkkannen op het wagentje. (Brlić-Mažuranić 2014: 31, eigen vertaling).

\section{Besluit}

In dit artikel gingen we samen met leerjongen Lapje op reis van de Kroatische maatschappij van de vroege twintigste eeuw naar de Nederlandse hedendaagse maatschappij. Lapje is de naam die de vertalers van Čudnovate zgode šegrta Hlapića, het beroemde kinderboek van Ivana Brlić-Mažuranić, hebben gekozen voor het hoofdpersonage. Bij het vertalen van een kinderboek zijn er een aantal zaken die in overweging moeten worden genomen.

Ten eerste moet er worden nagedacht over de specifieke positie van kinder- en jeugdliteratuur in het volledige spectrum van de literatuur waarbij opviel dat kinder- en jeugdliteratuur als ietwat minderwaardig wordt beschouwd. Dat komt door de verschillende functies ervan en omdat kinderboeken vaak veel universeler zijn dan volwassenenliteratuur waardoor ze minder gemakkelijk in een hokje te plaatsen zijn. Deze vaststellingen leidden tot de positie van de vertaler van dergelijke boeken die vaker dan in volwassenenliteratuur in de gecombineerde rol van vertaler en auteur zit. Ook heeft de vertaler van kinderliteratuur vaak meer vrijheid dan die van volwassenenliteratuur maar door de verschillende functies van kinderliteratuur, een didactische en een literaire, kunnen er soms conflicten ontstaan. Dit alles hangt samen met verschillende kindbeelden die auteurs hanteerden en die de vertalers hebben.

Verder stelt zich in elke vertaling de vraag naar de mate van aanpassingen. Na eerst de auteur en het boek te hebben voorgesteld, werd dieper ingegaan op de keuzes die de vertalers hebben gemaakt. Hun positie was om zo dicht mogelijk bij de brontekst te blijven maar net die aanpassingen door te voeren waar dat zou helpen bij de herkenbaarheid en identificatie en bij de leesbaarheid. Vanuit dat oogpunt zijn er in de vertaling, naast aanpassingen aan de verwoording, een aantal culturele aanpassingen doorgevoerd, waarbij de nadruk ligt op de naamgeving van de personages en op de gebruikte munteenheid. Elke naam in het boek heeft immers een speciale betekenis en de vertalers hebben ernaar gestreefd om die betekenis in de vertaling mee te nemen. Bij het vertalen van de namen en de munteenheid is vooral gekozen voor een naturaliserende strategie waarbij erop gelet is dat de vertaling in de doeltaal een door klank, gevoelswaarde of humor een vergelijkbaar effect heeft. Daarnaast werd er ook gebruik gemaakt van een neutraliserende strategie waarbij de naam van een personage werd vervangen door een omschrijving en sommige archaïsch aandoende woorden door een modernere pendant 
werden vervangen. Sommige namen werden enkel fonetisch aangepast en bij één naam werd met een verkleinend suffix een morfologische toevoeging gedaan.

\section{Bronnen en literatuurlijst}

Brlić-Mažuranić, Ivana (2014): Čudnovate zgode šegrta Hlapića. Pripovijest za malu djecu. Šest konaka šegrta Hlapića, igrokaz za djecu. Zagreb: Večernji list - Matica hrvatska Zagreb.

Brlić-Mažuranić, Ivana, Rajévic, Andrés, Razmilic, Jorge (2008): Las aventuras del aprendiz de Lápich. Madrid: Lual Ediciones.

Brlić-Mažuranić, Ivana (1994): ,Autobiografija‘. In: Izabrana djela I. Čudnovate zgode šegrta Hlapića. Autobiografski i drugi tekstovi. U svjetlu kritike (I.). Priredio Joža Skok, pp. 101-113. Zagreb: Naša djeca.

Brlić-Mažuranić, Ivana, Isenring, Toja, Maissen, Alfons (1983): Clapitsch: die wunderbare Reise eines Schusterjungen. München: C. Bertelsmann.

Brlić-Mažuranić, Ivana, Berson, Harold (1972): The brave adventures of Lapitch. New York: H.Z. Walck.

Ghesquière, Rita, Joosen, Vanessa, Van Lierop-Debrauwer, Helma (2014): Een land van waan en wijs. Geschiedenis van de Nederlandse jeugdliteratuur. Amsterdam: Atlas Contact.

Gouw, Evelyne (2016): Prentenboeken in vertaling. Een onderzoek naar de representatie van kindbeeld in prentenboeken en hun vertalingen uit de periodes rond 1900, 1950 en 2000. Universiteit Utrecht 2016. https://dspace.library.uu.nl/bitstream/handle/1874/342697/MA\%20 Scriptie\%20E.E.D.\%20Gouw\%203663639\%20RMA\%20Literair\%20Vertalen.pdf (25.7.2019).

Heimeriks, Netty, Van Toorn, Willem (1990): De hele Bibelebontse berg. De geschiedenis van het kinderboek in Nederland \& Vlaanderen van de middeleeuwen tot heden. Amsterdam: Querido.

Kamp, Iris, De Jong-Slagman, Janneke, Van Duijvenboden, Peter (2019): Jeugdliteratuur en didactiek. Handboek voor vo en mbo. Bussum: Uitgeverij Coutinho.

Koster, Cees (2005): ,En famille. De positie van vertaling in kinder- en jeugdliteratuur‘. In: Literatuur Zonder Leeftijd 19, pp. 57-69.

Koster, Cees (2005): ,Vertalen voor alle leeftijden? Culturele dynamiek en selectiemechanismen bij uitgeverijen van kinder- en jeugdboeken'. In: Filter. Tijdschrift over vertalen 12 (4), pp. 65-77

Machata, Martin (2013): ,O prijevodu i prevođenju Čudnovatih zgoda šegrta Hlapića na slovački‘. In: Libri et liberi : časopis za istraživanje dječje književnosti i kulture, pp. 209-224.

O'Sullivan, E. (2011): ,Comparative Children's Literature‘. In: Publications of the Modern Language Association of America 126 (1), pp. 189-196.

Oittinen, Riitta (2000): Translating for Children. New York: Garland Publishing, Inc.

Pentavec, Kristina (2017): Ivana Brlić-Mažuranić u kontekstu građanskog života u Brodu na Savi, Hrvatski studiji Sveučilišta u Zagrebu.

Rendulić, Morana (2015): Sintaktostilističke značajke bajki Ivane Brlić Mažuranić, Filozofski fakultet Sveučilišta u Rijeci.

Shavit, Zohar (1986): Poetics of Children's Literature. Athens \& London: The University of Georgia Press.

Stevens, John (1992): Language and Ideology in Childrens's fiction, Londen: Longman.

Van Coillie, Jan (2005): ,Vertalen voor kinderen: hoe anders‘. In: Literatuur Zonder Leeftijd 19, pp. $16-39$.

www.hlapic.org (s.d.): Hlapić - promicatelj hrvatske kulture (8.8.2019) 
Maarten Rombouts, lector / mrombout@ffzg.hr

Sveučilišta u Zagrebu, Filozofski fakultet, odsjek za germanistiku, katedra za nederlandistiku UI. Ivana Lučića 3, 10000, Zagreb, HR

Paola Brodej, student / brodej.paola@gmail.com

Sveučilišta u Zagrebu, Filozofski fakultet, odsjek za germanistiku, katedra za nederlandistiku Ul. Ivana Lučića 3, 10000, Zagreb, HR 
